\title{
Role of Advertisement in Formation of Values of Youth
}

\author{
${ }^{1,2}$ Kazan Federal University, Candidate of Political Sciences, Associate Professor of the Department of Public \\ Relations and Applied Political Science, 18 Kremlyovskaya str., Kazan, 420008, Russian Federation \\ E-mail: Aleksej.Nikitin@kpfu.ru
}

Received: 21st October 2017 Accepted: 16th November 2017, Published: 31st December 2017

\begin{abstract}
Evaluation of the existing sociological, philosophical and socio-psychological concepts for studying values and value orientations allows us to identify many approaches to the interpretation of these concepts. Despite the specific features of each study conducted in modern conditions, values are regarded as one of the most important components of not only individual, but also social consciousness, which has a significant influence on the formation of life attitudes and ways of their implementation, which determines the course of interaction of social actors.

The issue of value orientations is given great importance in many sciences. This is due to the fact that values play a major role in the integrative process on shaping not only the culture of an individual, but also the nation as a whole.

Values are a synthesis of the most important goals and norms of behavior, which emphasize the pre-eminent aspects in the perception of reality, orient persons to perform certain actions while forming their way of life. The system or set of dominant values in society expresses the specific features of the culture of the society.

To date, advertising is an indispensable attribute of all the media. Its main task is to ensure the sale of goods, services, and ideas of the advertiser. In this case, it is considered that the advertising appeal is perceived by the target audience when their social norms and values coincide. In this paper, we will attempt to determine the possibility of advertising not only for the translation of values, but also for their formation in the younger generation.
\end{abstract}

Key words: Advertisement, Youth, Life Values, MassMedia, Communication.

\section{Introduction}

The relevance of media research in the modern communicative process is due, on the one hand, to new trends in media consumption that affect the activity of the media, and on the other hand, the emergence of new information technologies leads to the complexity of the information process. Thus, a modern person receives information from the various means of mass communication having the opportunity to choose it, to dose it, but not everyone has the skills of independent analysis. This process is reflected in the formation of a person's world outlook.

Today it is not a secret that such socialization institutions as the family and school lose their importance; the mass media that create "social illusions of a technological nature" [1] aimed at solving specific political problems and forming public opinion become the dominant institution. Thus, the mass media fulfill not only the information function, but also socializing one introducing values, attitudes, and new trends. All this opens up opportunities for active manipulation of the mass consciousness. So, one of the effective tools for manipulating the public consciousness is advertising.

\section{Methodology}

We have chosen in the capacity of the basic methods a sociological survey (questionnaire by selective quota), general logic methods, content analysis of modern mass media, and a comparative analysis of data obtained by other methods. Quota survey method was chosen because of its high efficiency, verifiability of the data and the adequacy to the goals and objectives of the study [2,3, 4].Polls of students of the Kazan Federal University were conducted in 2012 and in 2016. The total population on the basis of reports on the contingent of students was 32000 people [5].The sample in each study was determined in accordance with the general statistic-probabilistic calculation rules and amounted to 550 people [6,7].The sample in the study of value orientations of citizens in the Republic of Tatarstan in the field of social well-being amounted to 385 people, with a total general population (the cities of the Republic of Tatarstan with a population of more than 50 thousand people) of 2532896 people [8].Content analysis allowed us to determine the main content of advertising messages, as well as to determine their basic media characteristics, such as distribution geography, target audience, circulation, thematic orientation and others $[9,10]$.

\section{Results}

Advertising is able using an accessible emotional and semantic form to form an essence of the competing ideas, programs, norms, and attractiveness of the advertised goods. Possessing a significant potential for psychological impact on a person at the same time, advertising is able to largely determine our perception of reality. Formation of the "right" worldview and its maintenance become a part of marketing [11].To date, advertising contains many stereotypes and values that are demonstrated by the media.

Value orientations are "elements of the internal (dispositional) structure of the personality, formed and fixed by the individual's life experience in the course of 
socialization and social adaptation processes, separating the significant (essential for a given person) and the insignificant (inessential) things through (non) acceptance by the individual of certain values realized in as a framework (horizon) of limiting meanings and fundamental goals of life, as well as determining acceptable means for their realization"[12].

Proceeding from this, we define in the capacity of an operational concept that value orientations are human perceptions of social reality, as well as the formed attitudes with which people are guided in certain life situations and which form the basic models of behavior in society.

On the one hand, value orientations are of a permanent nature; on the other hand, their stability is dynamic. Even in a society with formed values, their transformation is observed [13].

The central element of each social society is a certain idea of the way of life. In the event of undermining or destruction of this idea, there is a fundamental change in the society. With the weakening or falling of cultural or spiritual values in society, the development of such a society begins to decline. The cultural and legal frameworks of social communities give people not only an opportunity to meet their needs, but also are a kind of guarantor of order establishing certain rules and norms of life. Consequently, it can be noted that people living in a uniform social space, need such standards of conduct, aesthetic ideals, customs, dogmas, etc. It should also be noted that the younger generation is more prone to manipulating the media, which is due to the constant search for the best and readiness for any changes, and accordingly their values are in the process of modernization.

In today's world, advertising is the main intermediary in the relationship between consumers and manufacturers, thereby contributing to the progress that is taking place in society. Therefore, it is obvious that advertising has become one of the most important attributes of political, social, economic, spiritual and cultural life. It should also be noted that advertising is a stimulant of the production process, forcing manufacturers to work in a competitive environment and thereby improve the product quality and characteristics [14].

It is noteworthy that to date there is no single concept or approach that can explain such an economic, cultural, political and social phenomenon. Advertising is not only a way of informing consumers about new products, but also it is an element of the marketing system, a kind of art, a method of manipulating and controlling the human subconscious.

Experts and advertisers agree that in order for advertising to have the desired effect on the consumer, it must be a complex of elements: visual imagery (image, color transfer, composition of elements), audio sequence (timbre of voice, music and melody), motivations (settings, positive impression), texts (meaning, hints, accents), and symbols (symbol, logo, sign).
Advertising can cause a person's desire to buy a particular product only when it meets the requirements, attitudes and values of individuals. It is accepted to distinguish two concepts [15].According to the first concept, a person can be controlled using the lowest levels of the Maslow's needs pyramid [16, 17].Man here is represented as a not very intelligent driven being, following his or her instincts. Products advertised on the market do not always have competitive and quality characteristics, so advertisers have to use methods of manipulating the human mind, such as frequent repetition of advertising messages, suggestion, comparisons in favor of the advertised goods, etc., to attract attention to them.

The main idea of the second concept is that advertising is an art form and appeals to the aesthetic feelings of a person [18].Its beauty attracts attention from consumers. Many advertisers try to create such advertising.

Thus, on the one hand, to achieve its goal, advertising uses values significant for the society, while on the other, it forms these values, being an example and motivation source. Thus, it should be noted that a consumer buys those emotions or quality of life that he/she lacks or that he/she idealizes. In advertising, there is a replacement of concepts that we begin to use in everyday life. Thus, stereotypes are formed. At the same time, advertising often does not work with facts, but with "opinions". For example, chocolate brings happiness, live communication is identified with a telephone conversation, and coffee is a pledge of a good morning.

After analyzing the advertising market, it can be argued that, according to the cycles, several generations of modern Russian consumers have changed: "new Russians" with the desire after the Soviet deficit to buy more and more expensive to show their worth, and then "young professionals" or "managers" the main purpose of which was career growth in large companies. In the beginning of 2010, they were replaced by a new generation. These young people are guided by emotional consumption, the style difference, design (clothing, packaging, accessories, interior items) are important for them. At the same time, gender differences are eroding as never before. In this regard, the nature and style of advertising are being changed.

A modern time consumer is focused on emotional consumption. He/she tries to acquire those things which, in his or her opinion, lead to self-development in this or that sphere. With the emergence of this phenomenon, a large number of commercials have appeared where motivation and self-coping are at the first place.

According to the results of the study carried out by the authors in 2012-2016, the values of youth are organized as follows. The family value becomes a priority for more than $50 \%$ of respondents, more than $40 \%$ want to be financially secured and about $28 \%$ plan to make a career. Almost $40 \%$ of respondents (in 2012) and $30 \%$ (in 2016) consider to make a career, 
and to achieve public recognition as the most important goal in their lives. These data testify to the presence of a powerful motivational potential for the selfrealization of student youth, not only in its However, such value as health ceases to be in the lead. Only $19.3 \%$ think of health as a value, or a necessary life source.

Table 1: Sociological Study "Social Well-Being of Student Youth in Kazan 2012, 2016 "What are Your Life Priorities?"

\begin{tabular}{|l|r|l|}
\hline & Total (2016) & Total (2012) \\
\hline Make a career, achieve public recognition & $27.6 \%$ & $38.5 \%$ \\
\hline Be financially secured, do not need anything & $42.2 \%$ & $64.1 \%$ \\
\hline Have a good friendly family and children & $65.7 \%$ & $77.9 \%$ \\
\hline Be healthy and live a long time & $19.3 \%$ & $44.8 \%$ \\
\hline Have an interesting and creative work & $25.3 \%$ & $29.8 \%$ \\
\hline Don't know/No answer & $3.4 \%$ & $0.6 \%$ \\
\hline
\end{tabular}

The implementation and development of value orientations of student youth is a personal process mediated by a number of cognitive states, including the level of satisfaction with the conditions for the exercise of rights and freedoms, the realization of the potential of youth. To identify such cognitive-sensory professional, but also in social and civil development, as values set in many ways determine the strategy of individual behavior.

Table 2: Sociological study "Social well-being of student youth in Kazan 2012, 2016 "What, first of all, do young people lack today?"

\begin{tabular}{|l|r|r|}
\hline & Total (2016) & Total (2012) \\
\hline Material wealth & $24.4 \%$ & $30.8 \%$ \\
\hline Industriousness & $48.4 \%$ & $46.9 \%$ \\
\hline Self-reliance & $26.0 \%$ & $26.2 \%$ \\
\hline Initiatives, the ability to take risks & $20.2 \%$ & $18.9 \%$ \\
\hline Responsibility & $37.2 \%$ & $46.5 \%$ \\
\hline Refinement, politeness, morality & $59.6 \%$ & $46.2 \%$ \\
\hline State guarantees for basic rights & $22.6 \%$ & $21.3 \%$ \\
\hline Political freedoms & $3.8 \%$ & $4.3 \%$ \\
\hline Security of housing & $25.6 \%$ & $15.6 \%$ \\
\hline Don't know/No answer & $2.3 \%$ & $1.0 \%$ \\
\hline
\end{tabular}

The results of the research show that diligence, responsibility, refinement, and morality are considered by the respondents as the main factors ensuring the success of the life strategy. Thus, the largest number of respondents, with a difference in tenths of a percent, noted dissatisfaction with the level of development of such personal characteristics as "industriousness", "responsibility", "refinement, politeness, and morality". Today, as the young generation itself notes, the absence of any ideals, "moral relativism" is characteristic for them.

Thus, despite the fact that young people are active and ambitious, they strive to get a prestigious education, material and social status, at present there is a need to form a fundamentally different system of basic values that is based on the balance of personal and collective interests, material and spiritual well-being, and the development of a commitment to a multifaceted perfection of an individual, which is not reducible only to professional success and prestigious norms of material consumption [19]. components which largely determine the formation and dynamics of students' values and express self-esteem of the state of life, the following question was introduced: "What, first of all, do young people lack today?" (see Table 2).

\section{Summary}

According to the results of the study, it should be noted that advertising plays a significant role in the formation of values in people. Advertising is permanently broadcasted and remembered by people, and certain values and behaviors are permanently stored in memory and are reflected in the everyday life of each person together with advertising.

The results of the content analysis of commercials (2000s and 2017) make it possible to say that today their producers try to move away from the elementary demonstration of a product and the description of its qualities. Currently, advertising can cause special feelings that would be associated with the advertised product.

Over the years, the basic values that are covered by advertising have remained unchanged: family life, beauty and health, spiritual life, interests (friends, hobbies).So, in 2000, the share of videos showing vital values was $41 \%$, but in 2017 the number of advertisements demonstrating these values was only $30 \%$. Values of family and friendship are considered to 
be fundamental in the life of each person, so the percentage of these videos is very similar. Video advertising in 2000 in which a plot with family values is present, was $33 \%$ and with friendship values of $26 \%$. In video advertising, which we can observe today, the family values are shown in $30 \%$ of commercials, and friendship in $25 \%$. However, it should be also noted that in connection with the change in the rhythm of life, in fashion and human perception of individual things, the theme of self-realization is increasingly being addressed in commercials. The hero of the videos acts as a strong, self-confident person who is making progress relying on his/her abilities and capabilities. In 2000, advertising which reflected the person's desire for self-fulfillment was $0 \%$. In 2017, a demonstration of this model of behavior contains $15 \%$ of advertising videos.

In order to find an approach to consumers, video advertising producers often use social values as the basis of the advertising message storyline. It can also be said that the actualization of universal imperatives, such as love, friendship, good, family values, etc., becomes quite powerful convincing force in advertising.

Separately we want to note that at the moment in new commercials you can increasingly see reflection of such a value as self-development and the formation of personality.

\section{Conclusion}

In closing, we'd like to summarize the main conclusions, namely, that the advertisement exploits and actualizes the above human values. At the same time, we note that to date, advertising has become comprehensive, it is spread everywhere, is broadcasted by all means of mass communication, and crosses any geographical boundaries. Given such a massive nature of this communication, the values transmitted to it are easily absorbed, especially in the process of personality development and socialization. At the same time, the most prone to implantation of these settings is the youth cohort due to its immanent group characteristics; the youth has a tendency to search for something new, fundamentally ready for changes in life priorities and principles, and therefore it is easier for the youth than for other age groups to learn a new one.

\section{Acknowledgements}

The work is carried out according to the Russian Government Program of Competitive Growth of Kazan Federal University.

\section{References}

1. Yusupova A.M. Journalism as a factor in the formation of social illusions (on the example of socio-political publications of the Urals Federal District), the author's abstract of the thesis for a Candidate of Philology scientific degree, Yekaterinburg. - 2016
2. Blaxter, C. Hughes, M. Tiqht.How to Research, 2010. Open University Press, 328 P.

3. E.R. Babbie.The Basics of Social Research, 4th edition, 2007. Wadsworth Publishing, 576 P.

4. C.L. Brians, L. Willnat, J.B. Manheim, R.K. Rich. Empirical Political Analysis, 8th Edition, 2010. Prentice Hall, 448 P.

5. Information on the contingent of students (higher education) // Kazan (Volga region) Federal University site.URL: http://shelly.kpfu.ru/eksu/docs/F675216584/VO_na_01.10.2016.pdf (accessed date: 07.10.2016)

6. Philip H. Pollock III. The Essentials of Political Analysis, 4th edition, 2011. CQ Press College. $280 \mathrm{P}$.

7. Handbook of Public Policy Analysis: Theory, Politics, and Methods, 2007 / edited by Frank Fischer, Gerald J. Miller, Mara S. Sidney. CRC Press. 645 P.

8. Population of the Republic of Tatarstan // Territorial body of the Federal State Statistics Service of the Republic of Tatarstan.URL: http://tatstat.gks.ru/wps/wcm/connect/rosstat_t s/tatstat/ru/statistics/population/ (accessed date: 05.08.2016)

9. Neuendorf, Kimberly A. The content analisys guidebook / Kimberly A. Neuendorf, Cleavlend State University, USA - Los Angeles: SAGE, 2017. 456 P.

10. Boreus Kristina, Bergström Göran. Analyzing text and discourse. Eight approaches for social science. / Kristina Boreus, Göran Bergström, London: SAGE, 2017. 293 P.

11. Abushenko V.L. Value orientations // Sociology: Encyclopedia / Compilers:A.A. Gritsanov, V.L. Abushenko, G.M. Evelkin, G.N. Sokolova, O.V. Tereshchenko. - Mn.: The Book House, 2003.- 1312 p. - (World of Encyclopedias). - ISBN 985428-619-3.

12. Nikitina T.I. The role of advertising in Russian political marketing: a thesis for the degree of candidate of politicalsciences: 23.00.02 / T.I. Nikitin.Kazan, 2009 - P.3

13. Pendikova, I.G. Archetype and symbol in advertising: a textbook for university students in the specialties "Advertising", "Marketing", "Commerce (Trading)". - M.: UNITY-DANA, 2012., P. 155

14. Mokshantsev R.I. Psychology of advertising: Textbook. - M.: SRC INFRA-M, 2015., P. 122

15. Goldsmith, Elizabeth B. Consumer Economic. Issues and behavior. Third edition // Elizabeth B.Goldsmith, New York: Routledge, 2016. $562 \mathrm{P}$.

16. Li, Eldon Y.; Chang, Liang Shuo.; and Chang, Laurence F.K., "Exploring consumer value of cross-border online shopping: an application 
of means-end chain theory and Maslow's hierarchy of needs" (2016). PACIS 2016 Proceedings.

359.http://aisel.aisnet.org/pacis2016/359

17. Nurafazeera Yunus, Zalina MohdKasim, Vahid Nimehchisalem, NurIzyan Syamimi Mat Husin. Hierarchy of Needs in Residential Advertisements // Journal of Language and Communication, 3(1), 97-108 (2016), pp. 97108. - ISSN: 2289-649X

18. Hoffman, Barry Howard. The fine art of advertising: irreverent, irrepressible, irresistibly, ironic / Barry Howard Hoffman. Stewart, Tabori \& Chang, $2002-143$ P.

19. Nikitin A.A., Nikitina T.I. Modernization of health system in the context of National security of Russia // Journal of Legal, Ethical and Regulatory, Issues Volume 19, Special Issue, 2016. 